\title{
KEPUASAN PEMANGKU KEPENTINGAN DARI PERAN LEMBAGA MASYARAKAT PELESTARI PADI PANDANWANGI CIANJUR
}

\author{
Oleh: \\ Endah Lisarini*) \\ Ayi Khobul Nuryana**)
}

\begin{abstract}
Abstrak
Eksistensi seorang petani di Indonesia akan lebih kuat apabila bergabung dalam suatu kelompok atau organisasi pertanian. Kegiatan kelembagaan pertanian di Indonesia banyak diarahkan kepada pengembangan tanaman pangan khususnya padi, tidak terkecuali di Cianjur Jawa Barat. Masyarakat Pelestari Padi Pandanwangi Cianjur (MP3C) merupakan suatu lembaga pertanian yang berperan aktif mengembangkan dan melestarikan padi Pandanwangi sebagai varietas Indikasi Geografis. Eksistensi MP3C akan dilihat dari kepuasan para pemangku kepentingan terhadap perannya. Penelitian ini dilakukan dengan tujuan mengkaji : 1). Bagaimana keberadaan dan peran MP3C; 2). Seberapa besar kepuasan pemangku kepentingan terhadap peran dan kinerja MP3C. Terkumpul sejumlah 35 tanggapan dari responden yang terdiri dari petani Pandanwangi, pedagang dan konsumen beras Pandanwangi, pemerintah dan akademisi. Penentuan responden sebagai sampel dilakukan dengan teknik quota sampling. Terdapat 5 dimensi untuk mengukur kepuasan terhadap kinerja dan kepentingan lembaga MP3C. Dimensi tersebut meliputi tangible, reliability, responsiveness, assurance dan emphaty. Untuk menjawab tujuan penelitian pertama dilakukan analisis deskriptif kualitatif terhadap informasi dan tanggapan responden. Tujuan penelitian ke dua dijawab dengan metode analisis Customer Satisfaction Index (CSI) dan Importance and Performance Analysis (IPA). Hasil penelitian menunjukkan : 1) Keberadaan lembaga MP3C sangat penting bagi para pemangku kepentingan. MP3C berperan dalam mengontrol, mengawal, mengawasi dan membina petani padi Pandanwangi yang menjadi anggotanya; 2) Peran MP3C dianggap sangat penting oleh pemangku kepentingan dalam hal pembinaan dan penyuluhan, sedangkan kinerja MP3C dianggap memberikan rasa puas dengan nilai CSI sebesar $69.93 \%$. Keadaan demikian diharapkan dapat menjadi pertimbangan untuk perbaikan berkelanjutan dan keberlangsungan lembaga MP3C dalam upaya mengembangkan dan melestarikan padi Pandanwangi.
\end{abstract}

Kata kunci : kepentingan, kepuasan, kinerja lembaga pertanian.

\begin{abstract}
The existence of a farmer in Indonesia will be stronger when joining a farming group or organization. The activities of agricultural institutions in Indonesia are directed to the development of food crops, especially rice, including Cianjur, West Java. The Pandanwangi Cianjur Rice Conservation Society (MP3C) is an agricultural institution that plays an active role in developing and preserving Pandanwangi rice as a variety of Geographical Indications. The existence of MP3C will be seen from stakeholder satisfaction with its role. This research was conducted with the aim of reviewing: 1). How is the existence and role of the MP3C; 2). How much stakeholder satisfaction is there for the role and performance of MP3C. 35 responses were collected from respondents consisting of Pandanwangi farmers, Pandanwangi rice traders and consumers, government and academics. Determination of respondents as samples is done by quota sampling technique. There are 5 dimensions to measuring satisfaction with the performance and interests of MP3C institutions.
\end{abstract}


These dimensions include tangible, reliability, responsiveness, assurance and empathy. To answer the objectives of the first research qualitative descriptive analysis was carried out on the respondents' information and responses. The second research objective was answered by the analysis method of the Customer Satisfaction Index (CSI) and Importance and Performance Analysis (IPA). The results of the study indicate: 1) The existence of MP3C institutions is very important for stakeholders. MP3C has a role in controlling, overseeing, supervising and fostering the Pandanwangi rice farmers who are members; 2) The role of MP $3 C$ is considered very important by stakeholders in terms of guidance and counseling, while the performance of MP3C is considered to provide satisfaction with the CSI value of $69.93 \%$. Such a condition is expected to be a consideration for the continuous improvement and sustainability of the MP3C institution in an effort to develop and preserve Pandanwangi rice.

Key words : interests, satisfaction, performance of agricultural institutions.

*) Alumni Fakultas Sains Terapan UNSUR

**) Dosen Fakultas Sains Terapan UNSUR 


\section{PENDAHULUAN}

Di Cianjur Jawa Barat terdapat satu lembaga pertanian yaitu Masyarakat Petani Pelestari Pandanwangi Cianjur (MP3C) yang mempunyai peran utama mengawal, mengontrol dan mengawasi kegiatan pertanian pada komoditas padi maupun beras Pandanwangi guna melindungi keamanan produsen dan kepuasan konsumen, serta menjamin keaslian dari beras Pandanwangi tersebut (MP3C, 2015).

Keberlangsungan lembaga tidak terlepas dari peran serta aktif anggotanya. Sebaliknya petani anggotanya akan mendukung penuh dan loyal pada lembaga yang menaunginya apabila keberadaan dan peran lembaga dapat mewadahi dan memenuhi kebutuhan dan kepentingan petani anggotanya. Keadaan ini yang mendasari perlunya dilakukan penelitian dengan tujuan : 1) mengkaji keberadaan dan peran MP3C; 2) mengkaji kepuasan para pemangku kepentingan MP3C terhadap keberadaan dan perannya dalam melestarikan padi Pandanwangi.

Pada masa sekarang ini sebagian besar petani tergabung dalam organisasi pertanian baik di tingkat nasional maupun daerah dan baik yang pemerintah maupun swasta. Organisasi atau lembaga pertanian merupakan struktur organisasi yang mewadahi para anggotanya untuk mencapai tujuan tertentu dalam bentuk kelompok tani, gabungan kelompok tani, asosiasi komoditas pertanian dan komoditas pertanian nasional (Permentan No.67, 2016). Bergabungnya petani ke dalam suatu organisasi dilandasi adanya tujuan-tujuan tertentu di antaranya adalah untuk mendapatkan perlindungan lahan dan produk pertanian pangan, pembinaan maupun layanan (Anantanyu, 2011; Suardi dkk., 2016).

Salah satu organisasi pertanian di tingkat daerah yang mewadahi petani petani komoditas padi Pandanwangi adalah Masyarakat Pelestari Petani Pandawangi Cianjur (MP3C). MP3C dibentuk berdasarkan Peraturan Daerah No. 19 tahun 2012 pasal 3 tentang maksud dari pelestarian Pandanwangi, yaitu pelestarian dan perlindungan padi Pandanwangi Cianjur melalui pembinaan, pengawasan perlindungan dan pengendalian varietas padi Pandanwangi Cianjur guna menjamin ketersediaan produk padi Pandanwangi Cianjur, keberadaan petani Pandanwangi Cianjur, serta keberadaan lahan budidaya padi Pandanwangi Cianjur berkelanjutan. Keberadaan dan keberlanjutan suatu lembaga sangat diipengaruhi oleh dukungan dari para pemangku kepentingannya. Besar kecilnya dukungan dari para pemangku kepentingan tidak terlepas dari kepuasan mereka atas keberadaan dan peran atau kinerja lembaga.

Kepuasan konsumen dapat terpenuhi karena terdapat kesesuaian antara apa yang diharapkan dengan apa yang diterima atas kinerja produk atau hasil yang dirasakan (Putriandari, 2011; Ardian, 2015). Kinerja berkaitan dengan hasil kerja dan hasil kerja merupakan jasa atau layanan yang dirasakan oleh penerima hasil kerja. Seberapa puas seseorang terhadap kinerja pihak pemberi layanan, sangat ditentukan oleh kesesuaian kualitas layanan yang diharapkan dengan yang diterima. Kualitas layanan dapat diukur melalui sejumlah atribut layanan atau jasa.

Dalam Kotler \& Keller (2012) disebutkan atribut jasa meliputi : a) bersifat tidak wujud; b) tidak terpisahkan atau melekat pada pemberi layanan; c) beragam; d) tidak dapat disimpan. Sejumlah penelitian terdahulu telah mengakaji tingkat kepuasan kinerja melalui mengukur tingkat kepentingan dan kinerja dengan metode Customer Satisfaction Index (CSI) dan Important Performance Analysis (IPA)(Listiawati, 2010; Diyahya, 2016; Patimah, 2016).

\section{METODE PENELITIAN}

Penelitian ini dilaksanakan di wilayah kerja MP3C di kabupaten Cianjur meliputi tujuh kecamatan yaitu Cianjur, Cugenang, Cilaku, Warungkondang, Gekbrong, Cibeber dan Campaka. Dasar penentuan lokasi tersebut adalah mengingat bahwa ke tujuh kecamatan 
merupakan wilayah Indikasi Geografis Pandanwangi. Sementara itu MP3C mewadahi petani-petani Pandanwangi di wilayah tersebut. Populasi dalam penelitian ini adalah para pemangku kepentingan MP3C terdiri dari petani Pandanwangi, Pemerintah Daerah Cianjur, Dinas Pertanian Tanaman Pangan dan Hortikultura Cianjur, akademisi dan pebisnis (perusahaan) beras Pandanwangi, pengurus MP3C dan konsumen. Dari populasi tersebut diharapkan akan diperoleh tanggapan mengenai keberadaan dan peran MP3C. Jumlah para pemangku kepentingan cukup banyak namun tidak dapat diketahui dengan pasti. Berdasarkan hal itu, maka perlu dilakukan sampling untuk menghemat waktu dan biaya (Sugiyono, 2011; 2015). Sampling yang dilakukan adalah non probability sampling dengan teknik purposive dan quota sampling. Dalam penelitian ini jumlah sampel sebanyak 39 responden terbagi ke dalam 17 petani, 6 pedagang, 3 konsumen, 4 akademisi, 7 pengurus dan 2 orang dari pemerintah daerah Cianjur dan Disperta Cianjur.

Pada penelitian ini, variabel yang dikaji adalah : tangible (hal yang wujud), reliability (kehandalan), responsiveness (tanggungjawab), assurance (jaminan), emphaty (empati) dan customer satisfaction (kepuasan konsumen). Variabel-variabel penelitian tersebut diukur melalui indikator-indikator pada tabel 1.

Tabel 1. Operasionalisasi Variabel Penelitian.

\begin{tabular}{|c|c|c|c|}
\hline $\begin{array}{c}\text { Variabel } \\
\text { Penelitian }\end{array}$ & Konsep Variabel & Indikator & Skala \\
\hline $\begin{array}{c}\text { Tangible } \\
\left(\mathrm{X}_{1}\right)\end{array}$ & $\begin{array}{l}\text { Menurut Zoeldhan (2012) pelayanan bukti fisik } \\
\text { biasanya berupa sarana dan prasarana berupa } \\
\text { pelayanan yang tersedia, teknologi pelayanan yang } \\
\text { digunakan, performance pemberi pelayanan yang } \\
\text { dapat sesuai dengan karakteristik pelayanan yang } \\
\text { diberikan dalam menunjukkan prestasi kerja yang } \\
\text { bisa diberikan dalam bentuk pelayanan fisik yang } \\
\text { dapat dilihat. }\end{array}$ & $\begin{array}{l}\text { 1. Keberadaan gedung } \\
\text { sekertariat MP3C } \\
\text { 2. Kenyamanan gedung } \\
\text { sekertariat MP3C }\end{array}$ & Ordinal \\
\hline $\begin{array}{l}\text { Reliability } \\
\qquad\left(X_{2}\right)\end{array}$ & $\begin{array}{l}\text { Menurut Zoeldhan (2012) kehandalan merupakan } \\
\text { suatu bentuk ciri khas atau suatu karakteristik dari } \\
\text { pegawai yang memiliki prestasi kerja tinggi. }\end{array}$ & $\begin{array}{ll}\text { 1. Pembinaan } & \text { yang } \\
\text { dilakukan MP3C } & \\
\begin{array}{ll}\text { 2. Penyuluhan } & \text { yang } \\
\text { diberikan MP3C } & \end{array}\end{array}$ & Ordinal \\
\hline $\begin{array}{c}\text { Responsiveness } \\
\left(X_{a}\right)\end{array}$ & $\begin{array}{l}\text { Menurut Tjiptono (2007) yaitu keinginan para staf } \\
\text { dan karyawan untuk bisa membantu para } \\
\text { pelanggan dan memberikan sebuah pelayanan } \\
\text { dengan tanggap. }\end{array}$ & $\begin{array}{lr}\text { 1. Mengontrol } & \text { kegiatan } \\
\text { budidaya } & \text { padi } \\
\text { Pandanwangi } & \\
\text { 2. Mengontrol } & \text { legalitas } \\
\text { pemasaran } & \end{array}$ & Ordinal \\
\hline $\begin{array}{c}\text { Assurance } \\
\left(X_{4}\right)\end{array}$ & $\begin{array}{l}\text { Menurut Salim (2007) asuransi adalah suatu } \\
\text { kemauan untuk menetapkan kerugian-kerugian } \\
\text { kecil (sedikit) yang sudah pasti sebagai pengganti } \\
\text { atau substitusi kerugian-kerugian besar yang belum } \\
\text { terjadi. }\end{array}$ & $\begin{array}{l}\text { 1. Mengawal legalitas } \\
\text { benih } \\
\begin{array}{l}\text { 2. Perlindungan } \\
\text { konsumen dan } \\
\text { produsen }\end{array}\end{array}$ & Ordinal \\
\hline $\begin{array}{c}\text { Empathy } \\
\left(X_{5}\right)\end{array}$ & $\begin{array}{l}\text { Menurut Nursodik (2010) empati adalah perhatian } \\
\text { secara individual yang bisa diberikan perusahaan } \\
\text { kepada pelanggan seperti kemudahan dalam } \\
\text { menghubungi sebuah perusahaan, kemampuan } \\
\text { karyawan untuk berkomunikasi dengan pelanggan, } \\
\text { dan kebutuhan pelanggannya. }\end{array}$ & $\begin{array}{l}\text { 1. Memberikan masukan } \\
\text { atau arahan yang } \\
\text { berkaitan dengan beras } \\
\text { atau padi Pandanwangi } \\
\text { 2. Menerima keluhan dari } \\
\text { anggota }\end{array}$ & Ordinal \\
\hline $\begin{array}{l}\text { Kepuasan } \\
\text { Konsumen } \\
\quad(Y)\end{array}$ & $\begin{array}{l}\text { Menurut Bachtiar (2011) kepuasan konsumen } \\
\text { merupakan suatu perasaan positif konsumen yang } \\
\text { berhubungan dengan produk atau jasa selama } \\
\text { menggunakan atau setelah menggunakannya. }\end{array}$ & $\begin{array}{l}\text { 1. Pembinaan dan } \\
\text { penyuluhan yang tepat } \\
\text { sasaran } \\
\text { 2. Bantuan dan layanan }\end{array}$ & Ordinal \\
\hline
\end{tabular}




\section{HASIL DAN PEMBAHASAN}

Pengumpulan data kuantitatif dilakukan terhadap 39 responden yang terdiri dari petani Pandanwangi, Pemerintah Daerah Cianjur, Dinas Pertanian Tanaman Pangan dan Hortikultura Cianjur, akademisi dan pebisnis (perusahaan) beras Pandanwangi, pengurus MP3C dan konsumen. Karakteristik responden dalam penelitian ini meliputi : jenis kelamin, usia, tingkat pendidikan, posisinya sebagai pemangku kepentingan MP3C dan lamanya mengetahui keberadaan MP3C. Seluruh karakteristik tersebut dapat dijelaskan pada tabel 2 berikut ini.

sesuai kebutuhan

anggota MP3C

Dari tabel 2 dapat dilihat bahwa responden yang memberikan tanggapan mengenai kinerja dan kepuasannya terhadap keberadaan dan peran MP3C dapat dideskripsikan sebagai berikut : 85\% responden laki-laki yang berusia terbanyak di atas 50 tahun dengan latar belakang pendidikan terbanyak sarjana strata satu. Terbanyak dari responden tersebut berprofesi sebagai petani yang telah mengenal keberadaan MP3C lebih dari tiga tahun. Mereka yang merupakan petani dan telah mengenal lebih dari tiga tahun MP3C juga merupakan pengurus dan sekaligus anggota MP3C.

Tabel 2. Karakteristik Responden.

\begin{tabular}{|c|c|c|c|c|}
\hline No & Keterangan & Kategori & Jumlah & Persentase $\%$ \\
\hline \multirow[t]{3}{*}{1} & Jenis Kelamin & Laki-laki & 33 & 85 \\
\hline & & Perempuan & 6 & 15 \\
\hline & Total & & 39 & 100 \\
\hline \multirow[t]{6}{*}{2} & Usia & $<20$ & - & - \\
\hline & & $20-30$ & 10 & 26 \\
\hline & & $31-40$ & 5 & 13 \\
\hline & & $41-50$ & 4 & 10 \\
\hline & & $>50$ & 20 & 51 \\
\hline & Total & & 39 & 100 \\
\hline \multirow[t]{7}{*}{3} & Tingkat Pendidikan & Tidak Tamat SD & 1 & 2 \\
\hline & & SD & 7 & 18 \\
\hline & & SMP & 2 & 5 \\
\hline & & SMA & 11 & 28 \\
\hline & & Diploma & 1 & 3 \\
\hline & & Sarjana & 17 & 44 \\
\hline & Total & & 39 & 100 \\
\hline \multirow[t]{6}{*}{4} & Apa posisi Bapak/Ibu & Petani & 17 & 44 \\
\hline & dalam hubungannya & Pedagang & 6 & 15 \\
\hline & dengan Masyarakat & Konsumen & 3 & 8 \\
\hline & Pelestari Padi & Akademisi & 4 & 10 \\
\hline & Pandanwangi Cianjur & Pengurus & 7 & 18 \\
\hline & (MP3C)? & Lainnya & 2 & 5 \\
\hline & Total & & 39 & 100 \\
\hline \multirow[t]{6}{*}{5} & Sudah berapa lama & $<$ 1Tahun & 3 & 8 \\
\hline & mengetahui & 1 Tahun & 2 & 5 \\
\hline & keberadaan MP3C? & 2 Tahun & 5 & 13 \\
\hline & & 3 Tahun & 2 & 5 \\
\hline & & $>3$ Tahun & 27 & 69 \\
\hline & Total & & 39 & 100 \\
\hline
\end{tabular}




\begin{tabular}{ccccc}
\hline No & Keterangan & Kategori & Jumlah & Persentase \% \\
\hline $\mathbf{6}$ & Menjadi Pengurus & $<$ TTahun & - & - \\
& & - & - \\
& 1 Tahun & 1 & 14 \\
& 2 Tahun & 2 & 29 \\
& 3 Tahun & 4 & 57 \\
& $>$ 3 Tahun & $\mathbf{1 0 0}$ \\
7 & & - & 6 \\
& Total & 1Tahun & - & 14 \\
& Menjadi Anggota & 1 Tahun & 1 & 29 \\
& 2 Tahun & 2 & 57 \\
& 3 Tahun & 4 & $\mathbf{1 0 0}$ \\
\hline
\end{tabular}

Jawaban dari tujuan penelitian pertama adalah berupa deskripsi keberadaan dan peran MP3C. MP3C merupakan salah satu organisasi pertanian berbadan hukum yang didirikan oleh sekelompok petani yang peduli akan kelestarian padi Pandanwangi pada tahun 2014. Kantor MP3C berada di Jalan Kilometer Bandung pada KM 2 dari pusat kota Cianjur. Keberadaan kantor MP3C digunakan sebagai pusat informasi dan konsultasi hal-hal yang berkaitan dengan Pandanwangi. Adapun peran dari MP3C dapat dikelompokkan ke dalam beberapa peran yaitu : A. Mengontrol, meliputi : 1) Mengontrol daerah Indikasi Geografis; 2) Mengatur waktu tanam dan kegiatan budidaya; 3) Mengontrol legalitas pemasaran. B. Mengawal, mencakup : 1) Legalisasi Benih atau Sertifikasi Benih serta Badan Usaha; 2) Mengkoordinasi
Kegiatan Budidaya; 3) Pendataan atau Dokumentasi; 4) Perlidungan Konsumen dan Produsen. C. Mengawasi dan Membina.

Untuk menjawab tujuan penelitian ke dua, dilakukan analisis IPA dan CSI terhadap data respon para stakeholder terhadap kinerja atau peran MP3C. Responden memberikan tanggapannya terhadap lima atribut menyangkut keberadaan dan peran $\mathrm{MP} 3 \mathrm{C}$, meliputi : Tangible, Reliabilty, Responsibility, Assurance dan Emphaty. Data hasil respon tingkat kepentingan peran MP3C bagi para stakeholdernya dapat dilihat pada Tabel 3. Rata-rata skor setiap atribut peran MP3C dibandingkan ke dalam lima klas kategori dari sangat tidak penting sampai dengan sangat penting, seperti pada Gambar 1.

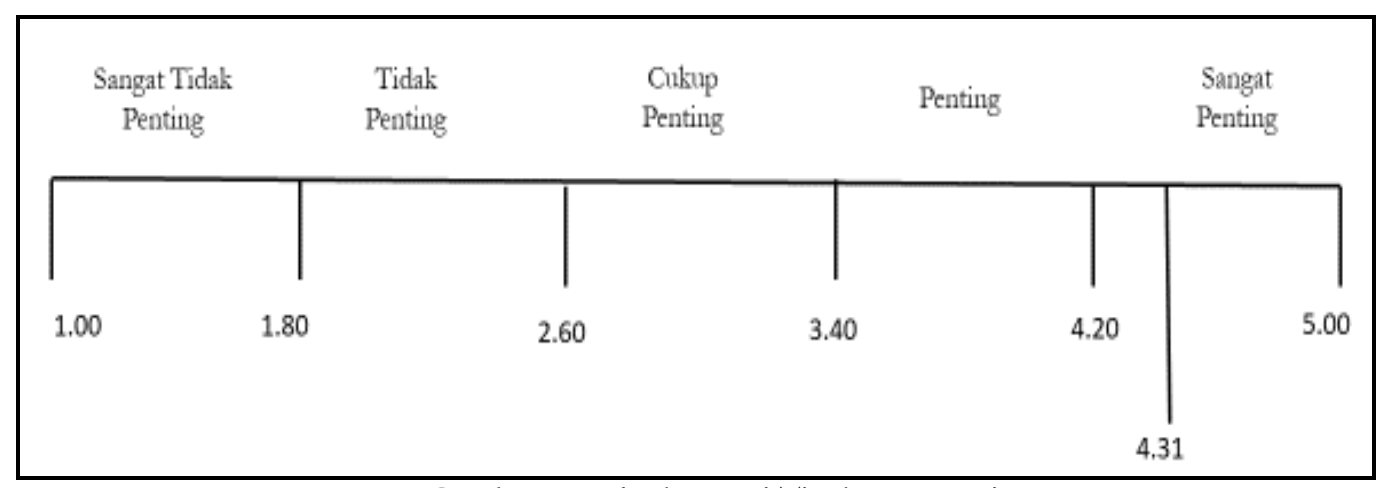

Gambar 1. Kelas kategori Tingkat Kepentingan

Skor rata-rata atribut Tangible dan Reliability masing-masing sebesar 4.31 termasuk kategori sangat penting. Sementara itu skor rata-rata Responsibility dan Assurance berturut-turut 4.5 dan 4.52 (kategori sangat penting). Kategori terendah yaitu hanya penting saja adalah pada atribut emphaty. Skor rata-rata atribut secara keseluruhan sebesar 4.31 dan termasuk dalam klas kategori sangat penting. 
Tabel 3. Penilaian Kepentingan Stakeholder Terhadap MP3C.

\begin{tabular}{|c|c|c|c|c|c|c|c|c|}
\hline No & Variabel & Pernyataan & 5 & 4 & 3 & 2 & 1 & $\begin{array}{l}\text { Rata- } \\
\text { rata }\end{array}$ \\
\hline $\mathrm{A}_{1}$ & \multirow{4}{*}{ Tangible } & Keberadaan Gedung Sekertariat MP3C. & 24 & 14 & 1 & 0 & 0 & 4,59 \\
\hline $\mathrm{A}_{2}$ & & Kenyamanan Gedung Sekertariat MP3C. & 11 & 22 & 6 & 0 & 0 & 4,13 \\
\hline $\mathrm{A}_{3}$ & & Tersedianya Lapangan Parkir. & 20 & 14 & 5 & 0 & 0 & 4,38 \\
\hline $\mathrm{A}_{4}$ & & Tersedianya fasilitas ruang tunggu. & 9 & 23 & 6 & 1 & 0 & 4,03 \\
\hline \multicolumn{3}{|c|}{ Rata-Rata } & & & & & & 4,31 \\
\hline $\mathrm{A}_{5}$ & & Pembinaan secara berkelanjut oleh MP3C. & 23 & 13 & 3 & 0 & 0 & 4,51 \\
\hline$A_{6}$ & & $\begin{array}{l}\text { Penyuluhan oleh MP3C yang dibarengi } \\
\text { dengan praktek secara langsung. }\end{array}$ & 26 & 11 & 2 & 0 & 0 & 4,62 \\
\hline $\mathrm{A}_{7}$ & Reliability & $\begin{array}{l}\text { MP3C mengupayakan sarana dan prasarana } \\
\text { yang dibutuhkan oleh setiap pihak terkait. }\end{array}$ & 10 & 21 & 8 & 0 & 0 & 4,05 \\
\hline$A_{8}$ & & $\begin{array}{l}\text { Pentingkah MP3C menyampaikan informasi } \\
\text { teknologi baru, pasar serta peluang usaha? }\end{array}$ & 15 & 12 & 11 & 1 & 0 & 4,05 \\
\hline \multicolumn{3}{|c|}{ Rata-rata } & & & & & & 4,31 \\
\hline $\mathrm{A}_{9}$ & \multirow{4}{*}{$\begin{array}{l}\text { Responsiv- } \\
\text { eness }\end{array}$} & $\begin{array}{l}\text { MP3C mengontrol kegiatan budidaya dan } \\
\text { pengolahan padi/beras Pandanwangi. }\end{array}$ & 15 & 17 & 7 & 0 & 0 & 4,26 \\
\hline $\mathrm{A}_{10}$ & & MP3C mengontrol Legalitas Pemasaran & 34 & 4 & 1 & 0 & 0 & 4,85 \\
\hline$A_{11}$ & & $\begin{array}{l}\text { Kemampuan MP3C untuk cepat tanggap } \\
\text { dalam menghadapi masalah yang timbul }\end{array}$ & 22 & 16 & 1 & 0 & 0 & 4,51 \\
\hline$A_{12}$ & & $\begin{array}{l}\text { Kecepatan pengurus MP3C dalam } \\
\text { menangani pengaduan pihak terkait }\end{array}$ & 19 & 15 & 5 & 0 & 0 & 4,36 \\
\hline \multicolumn{3}{|c|}{ Rata-rata } & & & & & & 4,50 \\
\hline \multicolumn{2}{|c|}{$\mathrm{A}_{13}$} & $\begin{array}{l}\text { MP3C mengawal legalitas benih serta } \\
\text { keaslian beras Pandanwangi }\end{array}$ & 33 & 6 & 0 & 0 & 0 & 4,85 \\
\hline $\mathrm{A}_{14}$ & \multirow[t]{3}{*}{ Assurance } & $\begin{array}{l}\text { MP3C memberikan Perlindungan konsumen } \\
\text { dan produsen }\end{array}$ & 29 & 8 & 2 & 0 & 0 & 4,69 \\
\hline $\mathrm{A}_{15}$ & & $\begin{array}{l}\text { MP3C memberikan pelayan/menyelesaikan } \\
\text { masalah sampai tuntas }\end{array}$ & 22 & 13 & 3 & 1 & 0 & 4,44 \\
\hline$A_{16}$ & & $\begin{array}{l}\text { Pengurus MP3C memberikan informasi } \\
\text { yang jelas dan mudah dimengerti kepada } \\
\text { pihak terkait }\end{array}$ & 13 & 17 & 8 & 1 & 0 & 4,08 \\
\hline \multicolumn{3}{|c|}{ Rata-rata } & & & & & & 4,52 \\
\hline \multirow{2}{*}{$\begin{array}{l}\mathrm{A}_{17} \\
\mathrm{~A}_{18}\end{array}$} & \multirow{4}{*}{ Empathy } & MP3C menerima keluhan dari pihak terkait & 11 & 13 & 12 & 3 & 0 & 3,82 \\
\hline & & $\begin{array}{l}\text { Memberikan masukan atau arahan yang } \\
\text { berkaitan dengan beras atau padi } \\
\text { Pandanwangi }\end{array}$ & 11 & 13 & 14 & 1 & 0 & 3,87 \\
\hline $\mathrm{A}_{19}$ & & $\begin{array}{l}\text { Memberikan perhatian khusus (individual) } \\
\text { atas masalah tertentu (khusus) }\end{array}$ & 7 & 16 & 8 & 0 & 0 & 3,56 \\
\hline$A_{20}$ & & $\begin{array}{l}\text { Pengurus MP3C mudah ditemui dan } \\
\text { dihubungi untuk berkonsultasi }\end{array}$ & 25 & 11 & 3 & 0 & 0 & 4,56 \\
\hline \multirow{2}{*}{\multicolumn{3}{|c|}{$\begin{array}{l}\text { Rata-rata } \\
\text { Rata-rata keseluruhan }\end{array}$}} & & & & & & 3,95 \\
\hline & & & & & & & & 4,31 \\
\hline
\end{tabular}




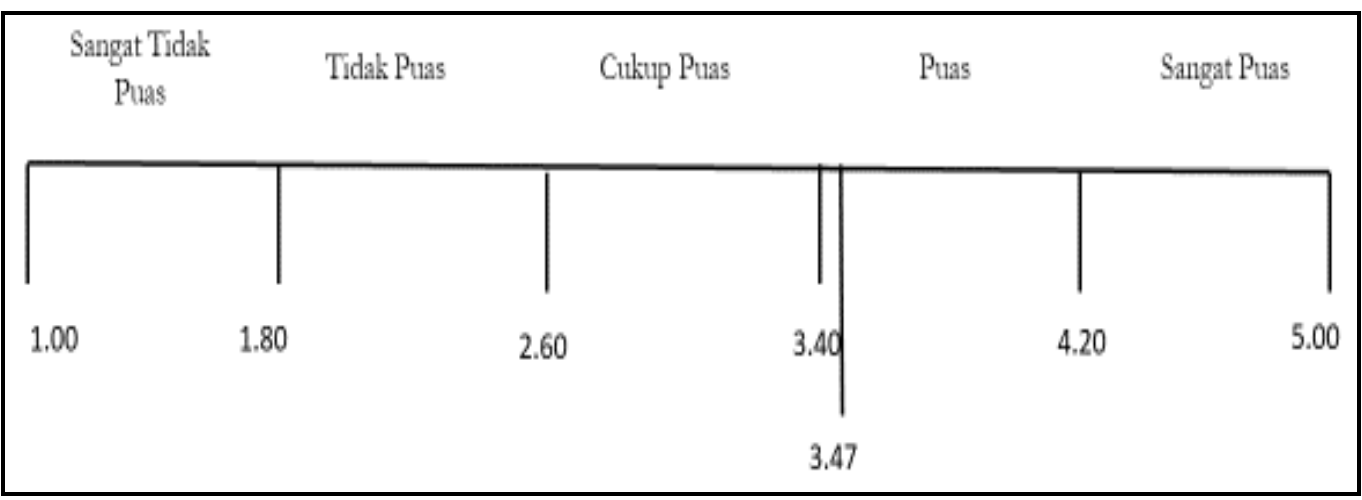

Gambar 2. Kelas kategori Tingkat Kepuasan.

Kelas interval tingkat kepuasan serupa dengan tingkat kepentingan. Skor rata-rata atribut Tangible dan Reliability masing-masing sebesar 3.82 termasuk kategori puas dan 3.06 (kategori cukup puas). Sementara itu skor rata-rata Responsibility dan Assurance berturut- turut 3.30 dan 3.63 (kategori puas). Atribut emphaty pun hanya dirasa puas oleh responden dengan skor rata-rata 3.53. Skor rata-rata atribut secara keseluruhan sebesar 3.47 dan termasuk dalam klas kategori puas.

Tabel 4. Tingkat Kepuasan Stakeholder Terhadap MP3C.

\begin{tabular}{|c|c|c|c|c|c|c|c|c|}
\hline No & Variabel & Pernyataan & 5 & 4 & 3 & 2 & 1 & $\begin{array}{l}\text { Rata- } \\
\text { rata }\end{array}$ \\
\hline $\mathrm{A}_{1}$ & \multirow{4}{*}{ Tangible } & Keberadaan Gedung Sekertariat MP3C. & 9 & 22 & 7 & 1 & 0 & 4,00 \\
\hline $\mathrm{A}_{2}$ & & Kenyamanan Gedung Sekertariat MP3C. & 4 & 20 & 14 & 1 & 0 & 3,69 \\
\hline $\mathrm{A}_{3}$ & & Tersedianya Lapangan Parkir. & 12 & 16 & 10 & 1 & 0 & 4,00 \\
\hline $\mathrm{A}_{4}$ & & Tersedianya fasilitas ruang tunggu. & 3 & 19 & 15 & 2 & 0 & 3,59 \\
\hline \multicolumn{3}{|c|}{ Rata-Rata } & & & & & & 3,82 \\
\hline \multirow{2}{*}{$\begin{array}{l}A_{5} \\
A_{6}\end{array}$} & & Pembinaan secara berkelanjut oleh MP3C. & 2 & 9 & 21 & 7 & 0 & 3,15 \\
\hline & & $\begin{array}{l}\text { Penyuluhan oleh MP3C yang dibarengi } \\
\text { dengan praktek secara langsung. }\end{array}$ & 2 & 8 & 20 & 9 & 0 & 3,08 \\
\hline \multirow[t]{2}{*}{$\mathrm{A}_{7}$} & Reliability & $\begin{array}{l}\text { MP3C mengupayakan sarana dan prasarana } \\
\text { yang dibutuhkan oleh setiap pihak terkait. }\end{array}$ & 2 & 7 & 14 & 15 & 1 & 2,79 \\
\hline & & $\begin{array}{l}\text { Pentingkah MP3C menyampaikan } \\
\text { informasi teknologi baru, pasar serta } \\
\text { peluang usaha? }\end{array}$ & 3 & 13 & 16 & 7 & 1 & 3,21 \\
\hline \multicolumn{2}{|c|}{ Rata-rata } & & & & & & & 3,06 \\
\hline$A_{9}$ & \multirow{4}{*}{$\begin{array}{l}\text { Responsiv- } \\
\text { eness }\end{array}$} & $\begin{array}{l}\text { MP3C mengontrol kegiatan budidaya dan } \\
\text { pengolahan padi/beras Pandanwangi. }\end{array}$ & 2 & 19 & 13 & 5 & 0 & 3,46 \\
\hline$A_{10}$ & & MP3C mengontrol Legalitas Pemasaran & 15 & 12 & 4 & 8 & 0 & 3,87 \\
\hline$A_{11}$ & & $\begin{array}{l}\text { Kemampuan MP3C untuk cepat tanggap } \\
\text { dalam menghadapi masalah yang timbul }\end{array}$ & 2 & 8 & 15 & 14 & 0 & 2,95 \\
\hline $\mathrm{A}_{12}$ & & $\begin{array}{l}\text { Kecepatan pengurus } \mathrm{MP} 3 \mathrm{C} \text { dalam } \\
\text { menangani pengaduan pihak terkait }\end{array}$ & 2 & 10 & 10 & 17 & 0 & 2,92 \\
\hline \multicolumn{2}{|c|}{ Rata-rata } & & & & & & & 3,30 \\
\hline $\mathrm{A}_{13}$ & & $\begin{array}{l}\text { MP3C mengawal legalitas benih serta } \\
\text { keaslian beras Pandanwangi }\end{array}$ & 11 & 18 & 9 & 1 & 0 & 4,00 \\
\hline \multirow[t]{2}{*}{$\mathrm{A}_{14}$} & & MP3C memberikan Perlindungan & & & & & & \\
\hline & Assurance & $\begin{array}{l}\text { konsumen dan produsen } \\
\text { MP3C memberikan pelayan/menyelesaikan }\end{array}$ & 10 & 14 & 13 & 2 & 0 & 3,82 \\
\hline $\mathrm{A}_{15}$ & & masalah sampai tuntas & 6 & 7 & 14 & 12 & 0 & 3,18 \\
\hline $\mathrm{A}_{16}$ & & $\begin{array}{l}\text { Pengurus MP3C memberikan informasi } \\
\text { yang jelas dan mudah dimengerti kepada } \\
\text { pihak terkait }\end{array}$ & 7 & 9 & 20 & 3 & 0 & 3,51 \\
\hline Rata & & & & & & & & 3,63 \\
\hline
\end{tabular}




\begin{tabular}{|c|c|c|c|c|c|c|c|c|}
\hline No & Variabel & Pernyataan & 5 & 4 & 3 & 2 & 1 & $\begin{array}{l}\text { Rata- } \\
\text { rata }\end{array}$ \\
\hline$A_{17}$ & & $\begin{array}{l}\text { MP3C menerima keluhan dari pihak } \\
\text { terkait }\end{array}$ & 5 & 9 & 13 & 12 & 0 & 3,18 \\
\hline $\mathrm{A}_{18}$ & Empathy & $\begin{array}{l}\text { Memberikan masukan atau arahan yang } \\
\text { berkaitan dengan beras atau padi } \\
\text { Pandanwangi }\end{array}$ & 7 & 10 & 16 & 6 & 0 & 3,46 \\
\hline $\mathrm{A}_{19}$ & & $\begin{array}{l}\text { Memberikan perhatian khusus (individual) } \\
\text { atas masalah tertentu (khusus) }\end{array}$ & 5 & 10 & 15 & 9 & 0 & 3,18 \\
\hline $\mathrm{A}_{20}$ & & $\begin{array}{l}\text { Pengurus MP3C mudah ditemui dan } \\
\text { dihubungi untuk berkonsultasi }\end{array}$ & 23 & 8 & 5 & 3 & 0 & 4,31 \\
\hline $\begin{array}{l}\text { Rata } \\
\text { Rata }\end{array}$ & $\begin{array}{l}\text { rata } \\
\text { rata keselur }\end{array}$ & & & & & & & $\begin{array}{l}3,53 \\
3,47\end{array}$ \\
\hline
\end{tabular}

Hasil CSI ternyata sama dengan skor rata-rata tanggapan responden yaitu berada pada kategori puas atau berada pada rentang $60 \%<$ CSI $\leq 80 \%$. Selanjutnya skor kineja

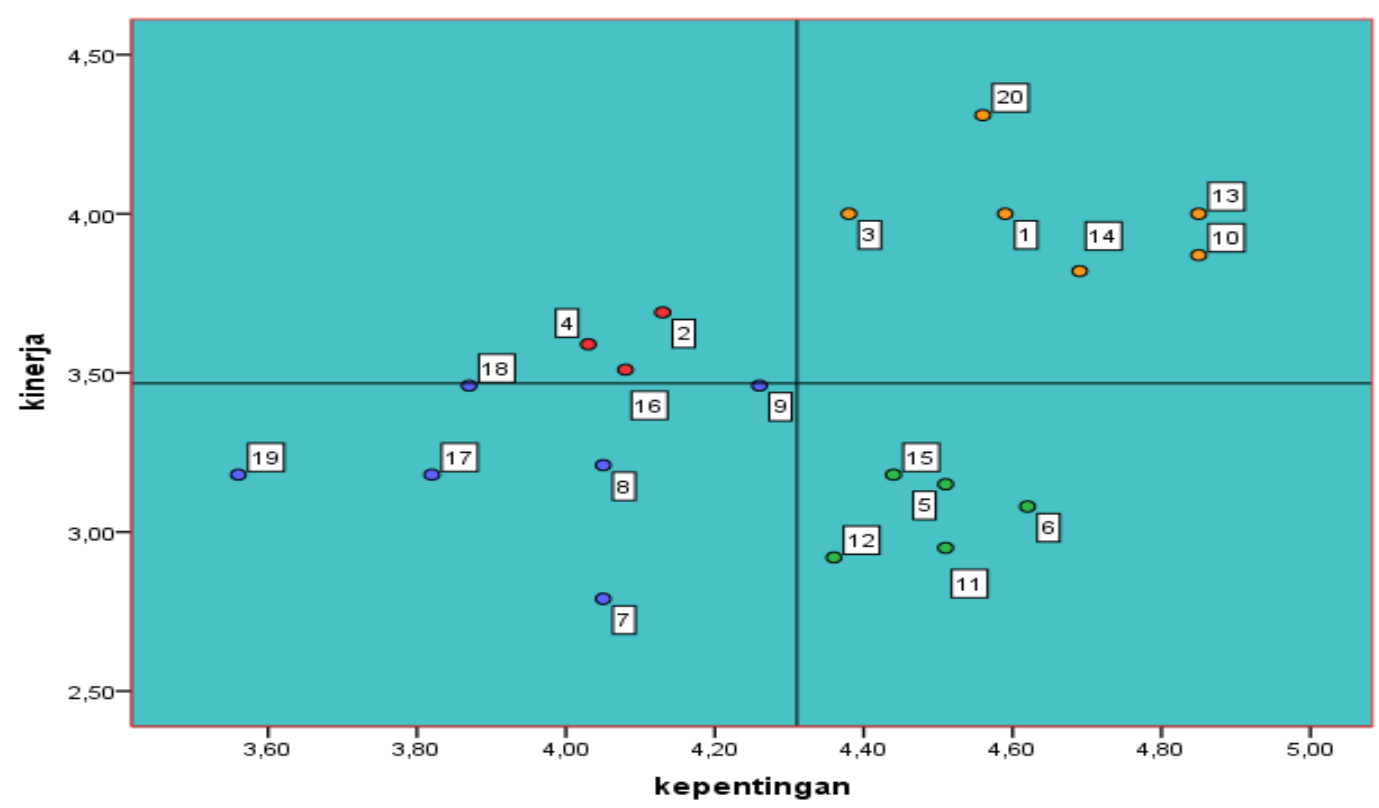

Gambar 3. Diagram Kartesius IPA Peran MP3C.

Kuadran I Prioritas Utama

Atribut-atribut yang berada pada kuadran ini dianggap sangat penting oleh stakeholder tetapi pelayanan kinerjanya kurang memuaskan. Beberapa atribut seperti pembinaan secara berkelanjutan, penyuluhan yang dibarengi dengan praktek secara langsung, kemampuan MP3C untuk cepat tanggap dalam menghadapi masalah yang timbul, kecepatan pengurus MP3C dalam menangani pengaduan pihak terkait serta mampu memberikan pelayanan atau menyelesaikan masalah sampai tuntas. Hal tersebut dikarenakan atribut tersebut tidak sepenuhnya ditanggung oleh MP3C dan skor kepuasan diplotkan pada diagram Kartesius. Hasil yang diperoleh, terlihat pada Gambar 3. 
legalitas benih serta keaslian beras Pandanwangi, MP3C memberikan Perlindungan konsumen dan produsen dan pengurus MP3C mudah ditemui dan dihubungi untuk berkonsultasi. Sehingga Lembaga MP3C harus dapat mempertahankan atribut kualitas pelayanan yang berada pada kuadran ini.

\section{Kuadran III Prioritas Rendah}

Atribut-atribut pada kuadran ini dianggap tidak terlalu penting oleh pelanggan dan pelayanannya kurang memuaskan seperti MP3C mengupayakan sarana dan prasarana yang dibutuhkan oleh setiap pihak terkait, menyampaikan informasi teknologi baru, pasar serta peluang usaha, mengontrol kegiatan budidaya dan pengolahan padi/beras Pandanwangi, menerima keluhan dari pihak terkait, memberikan masukan atau arahan yang berkaitan dengan beras atau padi Pandanwangi dan memberikan perhatian khusus (individual) atas masalah tertentu (khusus). Dalam permasalahan ini Lembaga MP3C tidak harus segera berbenah dalam peran yang ada dalam kuadran 3 (tiga) dikarenakan peran dalam kuadran tersebut merupakan peran yang tidak seharusnya dipenuhi oleh MP3C seperti sarana dan prasarana yang harus disediakan oleh petani padi Pandanwangi atau Pemerintah yang seharusnya memberikan bantuan sarana dan prasarana.

\section{Kuadran IV Berlebihan}

Atribut-atribut yang berada pada kuadran ini dianggap tidak terlalu penting oleh stakeholder tetapi pelayanannya memuaskan seperti kenyamanan gedung sekertariat MP3C, tersedianya fasilitas ruang tunggu serta pengurus MP3C memberikan informasi yang jelas dan mudah dimengerti kepada pihak terkait. Hal ini dapat menjadi nilai tambah bagi Lembaga MP3C karena stakeholder merasa puas atas peran MP3C yang telah dirasakan.

\section{KESIMPULAN}

Kesimpulan yang dapat ditarik dari pembahasan hasil penelitian adalah sebagai berikut :

1.

P3C merupakan organisasi pertanian yang dibentuk oleh sekelompok petani pelestari Pandanwangi Cianjur pada tahun 2014 yang berbadan hukum. MP3C mempunyai peran mengontrol, mengawal, mengawasi dan membina para petani anggotanya khususnya dalam melestarikan dan mengembangkan padi Pandanwangi mulai dari hulu (pengadaan benih murni) hingga hilir (pemasaran berasnya), dan kepada para stakeholder umumnya.

2.

erdasarkan hasil analisis dengan CSI dan IPA, peran MP3C dirasakan sangat penting oleh para stakeholder dengan skor 4.31 (skala 1.00 - 5.00) namun hanya memberikan rasa puas saja dengan skor 3.47 (skala 1.00 5.00) atau nilai CSI sebesar 69.62 (puas) pada rentang $60 \%<$ CSI $<80 \%$.

\section{DAFTAR PUSTAKA}

Anantanyu. Sapja, 2011. Kelembagaan Petani: Peran Dan Strategi Pengembangan Kapasitasnya, Universitas Sebelas Maret. Surakarta.

Ardian. Idris, 2015. Analisis Kepuasan Konsumen Pembelianproduk Sepatu Adidas Original Melalui Sistem Online (Studi Kasus Komunitas 3foil.Id), Universitas Gunadarma. Depok.

Bachtiar, 2011. Analisa Faktor-faktor Yang Mempengaruhi Kepuasan Mahasiswa Dalam Memilih Politeknik Sawunggalih Aji Purwerejo, Dinamika Sosial Ekonomi 
Dinas Pertanian Tanaman Pangan dan Hortikultura. 2007. Jawa Barat Dalam Angka. Bandung

Diyahya. Irvan, Ketut. Sukiyono dan Badrudin. Redy, 2016. Analisis Tingkat Kepuasan Petani Jagung Terhadap Pelayanan Lembaga Pemasarannya di Kecamatan Lubuk Pinang Kabupaten Mukomuko, Universitas Bengkulu. Bengkulu

Kotler, P., Kevin L. Keller, Swee Hoon Ang, Siew Meng Leong, Chin Tiong Tan. 2012. Marketing Management. An Asian Perspective. Pearson Education South Asia Pte Ltd.

Listiawati. Ika, 2010. Analisis Tingkat Kepuasan Petani Terhadap Kinerja Penyuluh Lapangan di BP3K Wilayah Ciawi Kabupaten Bogor, Institut Pertanian Bogor. Bogor

MP3C, 2015. Permohonan Pendaftaran Indikasi Geografis Beras Pandanwangi Cianjur, Buku Persyaratan. Cianjur

Nursodik. Gunarjo dan Kanti Walujo, 2012. Wayang Sebagai Media Komunikasi dan Inspirasi, Pustaka Stsi. Bandung.

Patimah. Siti, Priyono. Basuki Sigit dan Rasyid. Wilman, 2016. Analisis Tingkat Kepuasan Konsumen Terhadap Pelayanan Usaha Benih Padi Cigeulis Di Balai Induk Padi Dan Palawija di Kabupaten Kepahiang Provinsi Bengkulu, Universitas Bengkulu. Bengkulu.

Peraturan Menteri Pertanian Nomor 273/Kpts/OT.160/4/2007 tentang Pedoman Pembinaan Kelembagaan Petani.

Peraturan Menteri Pertanian Republik Indonesia Nomo 67/Permentan/SM.050/12/

2016 Tentang Pembinaan Kelembagaan Petani.

Peraturan Daerah Kabupaten Cianjur. 2012. Pelestarian Dan
Perlindungan Padi Pandanwangi Cianjur.

Salim. Abbas, 2007. Asuransi dan Manajemen Risiko, Raja Grafindo Persada. Jakarta.

Stratford on Avon District Council, 2008. Costumer Satisfaction Index. (Online)

http://www.statford.gov.uf diakses Desember 2017.

Suardi, DKK. 2016. Potensi dan Peran Kelembagaan Pertanian dalam Perlindungan Lahan Pertanian Pangan di Provinsi Bali, Universitas Udayana. Denpasar.

Sugiyono, 2011. Statistika Untuk Penelitian, Alfabeta. Bandung. Sugiyono, 2015. Metode Penelitian Kuantitatif Kualitatif dan R\&D, Alfabeta. Bandung.

Tjiptono, 2007. Strategi Pemasaran. Edisi Pertama, AndiOfset.Yogyakarta..

Zoeldhan. 2012. Pengertian Keputusan Pembelian, http:/ / zoeldhaninformatika.blogsp ot.com/2012/02/pengertian-

keputusan-pembelian.html. Diakses Desember 2017 